\title{
CONQUISTA DO PALADAR: OS KAINGANG E OS GUARANI PARA ALÉM DAS CIDADELAS CRISTÃ ${ }^{1}$
}

\author{
MARTA AMOROSO \\ USP
}

Resumo

A documentação religiosa é tomada na presente discussão como via de acesso às formas que os Guarani e os Kaingang deram aos aldeamentos indígenas do Império no Paraná (1850-1889). Assim, a intenção inicial da análise se concentra em identificar em que termos a missão capuchinha autodefiniu sua prática entre os índios do Tibagi, programa associado aos mecanismos de conquista do paladar e mudança de hábitos das populações indígenas como forma de engajá-las nas frentes agrícolas, nos aldeamentos ou no mercado regional de trabalho. Tal cenário aparecerá, entretanto, como pano de fundo das experiências diferenciadas dos grupos Kaingag e dos grupos Guarani que orbitavam em torno dos aldeamentos do Império. Observa-se a dinâmica empreendida aos aldeamentos pelas populações indígenas no próprio locus onde a missão capuchinha e o programa oficial de "Catequese e Civilização" elegeram para a operação de conversão: a indústria dos índios.

1. Versões anteriores deste trabalho foram apresentadas no Seminário FUNARTE: Brasil 500 anos. Experiência e destino. Nação e região. (Rio de Janeiro e Campos, RJ, 25 a 28 de oulubro de 2000) coordenado por Ribamar Bessa Freite e no XXIII Encontro Anual da ANPOCS, Caxambu, MG (19 a 23 de outubro de 1999), no Grupo de Trabalho "História e etnologia", coordenado por Dominique Gallois e Denise Fajardo Grupione. A pesquisa sobre os aldeamentos indígenas no Império foi realizada no contexto de minha tese de doutorado (Amoroso, 1998b) orientada por Manuela Carneiro da Cunha e recebeu apoio da CAPES e da FAPESP. 
I III mi idos do século XIX, um número expressivo de grupos indígeInıs viu missionírios católicos desembarcar em suas aldeias. Amparados pelo R'gulamento da "Catequese e Civilização" (1845), os religiosos dispunhamsc' a habitar junto às populações indígenas, educá-las para o trabalho e monlar com elas equipamentos produtivos. Novamente, a Igreja Católica era chamada à condução do projeto de catequese, dessa vez entregue à Ordem Menor dos Frades Capuchinhos. A partir de 1842, uma centena de frades italianos será encaminhada ao território de ocupação tradicional dos índios agora alcançado pela fronteiras do Império.

O aldeamento de São Pedro de Alcântara - cujo nome homenageava o Imperador - instalou-se no Paraná entre 1855 e 1895, sendo uma das mais duradouras e bem documentadas experiências de aldeamento do período. Seu missionário, Frei Timotheo de Castelnovo, costumava declarar - citando o jesuíta P. Antônio Vieira - que os índios impunham o "peito de bronze" ao trabalho de catequese. De fato, o modelo de intermediação do missionário para com as populações indígenas não se praticava prioritariamente pela conversão ao catolicismo. O projeto de catequese e civilização dos índios foi buscado por meio do trabalho dos Guarani (tanto os grupos Kaiowá como os Nandeva e Mbya, também presentes nos aldeamentos) e dos Kaingang em plantações extensivas de cana-de-açúcar, utilizada na produção de açúcar e cachaça, produtos apreciados pelos índios. Supunha-se que as mudanças almejadas para as populações nativas processavam-se mediante a conquista do paladar, por acostumar os índios ao gosto picante, salgado e doce da civilização.

Ainda que fadados ao fracasso, devido, em parte, à dimensão continental na qual se propunham a atuar, os aldeamentos capuchinhos do Império deixaram marcas profundas, por exemplo, na legislação indigenista, por meio da figura jurídica da "Tutela dos Índios" concebida nesse momento. Foi no contexto dos aldeamentos capuchinhos que o conceito de tutela dos índios ganhou um sentido diverso do que havia sido empregado no início do século XIX. ${ }^{2}$ Passava-se a estabelecer que o diretor dos aldeamentos

2. A tutela dos índios aparece na Lei de 1831, com o sentido de garantir segurança ans índios libertados da servidão, dirigia-se àqueles que estavam $\mathrm{cm}$ cativeiro por motivo da Carta Régia de 1808. A tutela dizia respeito exclusivamente aos índios submetidos ao cativeiro. Em 183., um novo decreto da Coroa encarregava provisoriamente os Juízes de Órfãos de proteger e administrar os bens pertencentes aos índios, em substituição aos ouvidores 
respondia como procurador dos índios e era também responsável pela tutela (le direito público sobre as terras indígenas. Os índios eram vistos como a expressão infantil de uma humanidade que deveria ser tutelada, até atingir um grau de civilidade. Como demonstrou Souza Filho (1993), a legislação da "Catequese e Civilização" de 1845, ao criar estrutura do serviço público para as populações indígenas aldeadas e estabelecer os cargos e as hierarquias dos funcionários dentro dos aldeamentos indígenas, deu aos diretores c tesoureiros dos aldeamentos poderes e atribuições dos Juízes de Órfãos. Os diretores dos aldeamentos tinham competência para demarcar as terras indígenas, prover de alimentos as aldeias, organizar o trabalho dos índios. Seus diretores, leigos ou religiosos, funcionavam também como guardiães das contas e dos bens dos índios. A tutela dos índios, introduzida originalmente no direito brasileiro com o sentido de proteger os bens e pessoas, com os aldeamentos do século XIX, passava a ser traduzida em limitação ao direito da população indígena. A catequese católica praticada no Império ditou, assim, o modelo de ação que determinava o lugar dos índios no Brasil. Na prática, reafirmando a articulação anteriormente estabelecida entre jesuítas e a administração colonial (B. Perrone-Moisés, 2003), os aldeamentos capuchinhos do Império servirão de reserva de mão-de-obra indígena, voltada tanto para os próprios aldeamentos como para os colonos.

A documentação religiosa relativa ao período, constituída de cartas, relatórios e memórias dos missionários, possibilita algumas revisões às teses da história dos índios no século XIX, baseadas na legislação do Império ou nos relatórios ministeriais. A partir dessas fontes oficiais, a política indigenista do século XIX havia sido identificada com o avanço sobre as terras dos índios, os aldeamentos sendo o resultado da necessidade de redefinição das terras indígenas pelo governo do Império no momento que

de Comarca, cargo extinto na ocasião. Foi com o Decreto $n^{2} 426$, de 24/07/1845, no já citado Regulamento acerca das missões de catequese e civilização dos índios, que a tutela dos índios passou a ter o sentido que irá figurar no Código Civil Brasileiro, o de atribuir aos índios "incapacidade relativa", até que estivessem adaptados à civilização do país. A tutela orfanológica aos índios será removida do Código Civil brasileiro em 1916, mas será reintroduzida no Estatuto do Índio de 1973. Comentando a solução de continuidade adotada pelo regime militar, que cria o Estatuto, diz Souza Filho: "O Estatuto do Índios, no intuito de romper com o passado recente de corrupção (do próprio Serviço de Proteção aos Índios), reafirma a teia de opressão pelo Direito oitocentista" (Souza Filho, 1993: 306). 
se promulgava a Lei de Terras de 1850 (Carneiro da Cunha, 1992; Souza Filho, 1993). O senso comum, por sua vez, tendeu a identificar os alcleamentos indígenas ou as missões católicas com cidadelas cristãs equipadas com igreja, cemitério e escola, tipo de urbanidade na qual os índios estavam contidos. As narrativas dos missionários revelam, no entanto, outra dinâmica, que resulta fundamentalmente da interação das políticas públicas com as políticas indígenas.

Assim, observar os atores religiosos relatando o que se passou com as populações indígenas nos aldeamentos nos auxilia, primeiramente, a identificar as relações consideradas essenciais para que o programa de "Catequese e Civilização": conferia-se os bons resultados do apostolado não pela conversão dos índios ao catolicismo, mas sim pela adesão destes às frentes de trabalho organizadas pela missão. Na maioria das vezes, isso não implicou uma convivência diuturna com os cristãos: os Kaingang e os Guarani ocupavam aldeias autônomas e distantes da sede da missão, prestando esporadicamente serviços nos aldeamentos, quando se somavam a trabalhadores africanos livres e funcionários assalariados. Chama-se aqui a atenção para a matriz marcadamente católica que fundamenta o princípio da tutela dos índios e nela se destaca o trabalho do índio como elemento essencial de uma estrutura de longa duração que articula as populações ameríndias ao governo colonial e imperial no Brasil, e que se perpetua na República no conceito de "catequese leiga" do Serviço de Proteção aos Índios. Às populações indígenas coube estabelecer o grau de proximidade ou de afastamento frente a programas do governo que visaram, invariavelmente, o trabalho do índio. $\mathrm{O}$ foco da análise recai, portanto, nas estratégias diferenciadas dos grupos Guarani e Kaingang, protagonistas centrais da história dos aldeamentos indígenas do Tibagi.

\section{Crânios e Cachaça}

$\mathrm{O}$ visitante que percorresse os estandes da Exposição Antropológica, inaugurada no Museu Nacional do Rio de Janeiro em 1822, superado o impacto que por certo a mostra obteve ao expor ao vivo uma família botocudo, trazida especialmente do aldeamento capuchinho de Mutum, no Espírito 
Santo, ${ }^{3}$ surpreender-se-ia com os objetos selecionados por Frei Timotheo de (astelnovo para representar a missão indígena de São Pedro de Alcântara, dirigida por ele no rio Tibagi, no Paraná. O missionário enviara uma intrigante coleção de peças da indústria dos índios, a saber: (1) um tecido dos Coroados; (2) uma cinta grosseira dos Índios Caiguás; (3) açúcar dos índios Coroados; (4) duas botijas de aguardente dos índios Coroados, tal qual se vende no depósito, e tirada das pipas; (5) açúcar dos moradores - fábrica de João Nepomuceno da Silveira; (6) um pouco de café do ordinário - e só para se ver a qualidade. ${ }^{4}$

A missão capuchinha fazia-se representar pelos objetos da indústria dos índios. Não se notava nenhuma restrição por parte dos expositores ou do missionário, ao teor (alcoólico) da catequese que se processava entre os índios do Paraná, financiada pelo governo monárquico e abençoada pela Ordem Menor dos Frades Capuchinhos. Ao contrário, o sucesso da catequese conferia-se pelo progresso da indústria de derivados da cana-de-açúcar, dentre os quais sobressaía a cachaça. No contex to do indigenismo da época, a montagem de destilarias de aguardente em um aldeamento indígena era fato corriqueiro e aceitável; outros aldeamentos desenvolveram a mesma atividade. ${ }^{5}$ A coleção de objetos do Paraná, expostos no Museu Nacional, completava-se com o crânio de um Kaiowá, acompanhado de uma nota de punho do missionário, que aludia à epidemia de varíola de 1877 , que se abatera

3. Tratava-se de uma família de índios Botocudo, composta de sete pessoas, que havia viajado para o Rio de Janciro no Paquete Ceará, acompanhada do intérprete do aldeamento de mais quatro caixas de objetos. Sobre o impacto da exposição "ao vivo" dessa família Botocudo, ver: John Monteiro, 1996. Aldeamento de índios Botocudo foi fundado em 1867 no rio Doce e administrado pelo capuchinho Frei Bento de Bobbio. Em 1873, passou a ser o único aldeamento da região do rio Doce, agregando a população indígena de outros dois aldeamentos: Pancas c Guandu (Desmoner, 1983).

4. Curitiba. DEAPP. Ms. Ofícios - Frei Timotheo de Castelnovo ao Presidente da Província do Paraná, 15/10/1881.

5. Também o aldeamento de São Jerônimo, no Paraná, investiu em plantações extensivas de canade-açúcar para a produção de açúcar e aguardente. Sobre a estratégia capuchinha de franquear cachaça aos índios, ver denúncia veiculada na imprensa pelo Serviço de Proteção aos índios (SPI), na década de 1920 (Horta Barbosa, Jomal A União, de 18/04/1920). 
sobre os Kaiowi das margens do rio Tibagi, causando centenas de mortes. ${ }^{6}$ 'lais objetos nas vitrines do Museu Nacional falavam das particularidades do conglomerado étnico que constituía um aldeamento indígena no século XIX: de sua composição plural, caracterizada pela presença de diferentes etnias indígenas, muitas vezes inimigas, e de moradores não-índios, produzindo e mantendo postos de venda de seus produtos agrícolas nos aldeamentos; do espectro da morte que rondava tais entrepostos de fronteira, sob a constante ameaça de epidemias; da produtividade dos índios aldeados. A mostra dialogava ainda com a ciência antropológica de uma época, praticada nos gabinetes dos museus, por meio da medição de crânios e de esqueletos e da classificação dos objetos da cultura material de populações distantes e desconhecidas. A ação missionária fundava-se, por sua vez, em premissas segundo as quais a população ameríndia, assimilada à etapa da "infância da humanidade", não detinha capacidade para o aprendizado, apenas para a imitação (Amoroso, 1998b). Os poderes tutelares promoviam a convivência dos índios com os "cristãos laboriosos", eufemismo empregado pelos missionários para justificar a presença de colonos aventureiros que habitavam nas fronteiras da civilização cristã, dispostos a desfrutar dos minguados recursos dos aldeamentos indígenas e dispor do trabalho dos índios. Em campo, a catequese atuava por meio da disseminação dos alimentosdroga (Sahlins, 1988), que traziam o gosto picante, salgado, doce e ardente da civilização.

Um número significativo de grupos indígenas foi contatado nesse momento pelas missões capuchinhas, passando algumas dessas populações a viver junto a aldeamentos financiados pelo governo do Império. Além dos índios, os outros protagonistas centrais dessa história foram os frades italianos da Ordem Menor, a quem a administração imperial encarregava do trabalho de "Catequese e Civilização" da população indígena. Ainda que a presença da missão católica junto aos povos indígenas não constituísse em si fato inédito no Brasil, sendo antes uma recorrência ao longo da história

6. Além do referido crânio Kaiowá, foram remetidos ao Muscu Nacional uma Menória dos Índioss Kamé (Kaingang), de Frei Luis de Cimitille, posteriormente publicada (Taunay, 1931), um vocabulário indígena organizado por Telêmaco Borba, um crânio Xavante, uma lança e uma fotografia de Frei Timotheo de Castelnovo com os índios (Rio de Janeiro. ANRJ. Ms. Terras e Colonizaşão - MACOP, 1831). 
colonial e imperial, a natureza do empreendimento que se instituiu em meados do século XIX, marcado pela submissão dos missionários ao poder secular, na condição de funcionários do governo imperial, deu a esse momento da história do indigenismo características bastante peculiares. Amparada pela legislação imperial, que indicava o setor italiano da Ordem dos Frades Menores Capuchinhos (OFMCap.) para o trabalho de catequese, ${ }^{7}$ a missão dos capuchinhos passou a deter, a partir de 1842, controle praticamente hegemônico da "questão indígena". ${ }^{8} \mathrm{O}$ marco final do período foi o advento do regime republicano, que instituiu a separação da Igreja do Estado e um novo modelo de indigenismo de Estado, leigo e de inspiração positivista, que fundamentou, nas primeiras décadas do século XX, o Serviço de Proteção aos Índios (SPI).

Em meio à crise que marcou os estertores do regime do padroado, ${ }^{9}$ os capuchinhos representavam a causa da Monarquia e da religião Católica do Império. Observada internamente, no entanto, a missão capuchinha no Brasil jamais se configurou como um corpo coeso de apoio ao governo do Império. Os aldeamentos indígenas compartilhavam um programa comum de catequese e civilização dos índios e se assemelhavam no aspecto administrativo; cada um deles, entretanto, significou uma experiência particular de contato dos frades italianos com a diversidade das populações indígenas com as quais se estabeleceram diferentes formas de mediação da Igreja. Pelo direito do padroado, o governo imperial reservava-se prerrogativas que suspendiam o poder do Vaticano em assuntos ligados às missões indígenas do Brasil, submetendo os frades às regras do governo: os capuchinhos consideravam-se e eram considerados funcionários do governo do Império. Os missionários destinados ao Brasil recebiam treinamento prévio na 'Sagrada Congregação da Propaganda Fide", no Vaticano,

7. Ver legislação relativa à "Catequese e Civilização" dos índios, que cita dirctamente os missionários capuchinhos: Regulamento $n^{2}$ 143, de 15 de março de 1842; Decreto $n^{2} 285$ de 21/06/1843; Lei n 317 de 21/10/1843 e, por fim, o Decreto n 2426 de 24/07/1845, que contém o Regulamento acerca das missões de catequese e civilização dos índios (Carneiro da Cunha, 1992).

8. Em escala mais reduzida, outras ordens religiosas católicas atuaram junto aos índios no fím do período. É o caso dos salesianos que estão no Mato Grosso, a partir de 1894, e dos dominicanos que se instalaram em Uberaba, $\mathrm{MG}$, em 1878, e nas margens do rio Araguaia em Goiás, em 1886 (Jorge, 1909:39-40).

9. Adquirido por aquele que funda ou dota uma igreja; direito de conferir benefícios eclesiásticos (Camargo, 1955). 
mulc ilprendiam a Língua Portuguesa e, em alguns casos, noções de línguas indligenas. Recebiam do governo do Brasil as passagens transatlânticas e as diúrias para sua manutenção nos aldeamentos, passando então a dever obrigações diretas ao governo imperial. O caráter oficial da missão capuchinha estava presente em todas as etapas do processo, da escolha do local mais conveniente à instalação da missão - realizada sob aparato militar - à sua extinção, por ato oficial do governo. A chegada do missionário em território brasileiro era registrada na Secretaria dos Negócios do Estado, encarregada de alocar os missionários nos aldeamentos, de onde só podiam se ausentar mediante autorização do governo central. Qualquer deslocamento deveria ser previamente autorizado pelo governo. Por vezes, o missionário, além do trabalho da catequese, acumulava as atribuições de Diretor do aldeamento. Nesse caso, deviam, por contrato, enviar relatórios periódicos ao governo imperial, o que caracterizava esse período da história dos índios e da missiologia como excepcionalmente bem documentado, ainda que pouco conhecido pela antropologia.

Esse foi um momento de sensível crescimento da Ordem Menor dos Capuchinhos no Brasil, cuja presença no país remonta ao século XVII. ${ }^{10} \mathrm{Já}$ no século XIX, alguns aldeamentos de "Catequese e Civilização" alcançaram certa notoriedade, uns por estarem articulados a projetos 'de colonização ambiciosos, como o do general Couto Magalhães no Araguaia e o de Teófilo Otoni em Minas Gerais, outros por terem mobilizado a opinião pública com as cenas de violência militar que sucederam à sua implantação caso do aldeamento entre os Xambiá, em Goiás e entre os Botocudo em Itambacuri, Minas Gerais. Na década de 1860, no contexto da Guerra do Paraguai, o governo central direcionou a missão de catequese para as províncias do Mato Grosso, Paraná e São Paulo, buscando com eles reforçar a

10. A historiografia da Ordem Menor diverge quanto a data inaugural da presença dos capuchinhos no Brasil, ver: Faria, 1982. Da Nembro registra tal presença nos primeiros momentos de colonização portuguesa na Bahia, ainda no século XVI; Faria tece a crônica da missão no Brasil, a partir de 1612, ano da chegada dos missionários capuchinhos Yves d'Evreux e Claude de Abbeville no Maranhão, acompanhando a expedição francesa comandada por Daniel de La Touche. A polêmica alude à dissidência que ocorre no interior da Ordem Menor entre claustrais e observantes, estes reivindicando o termo capuchinho como marca da autenticidade do movimento empreendido na Itália em 1525. Antes de 1550, a missão capuchinha italiana não havia se expandido por Portugal e suas colônias, o que faz discutível a presença de observantes nos trópicos anteriormente à tentativa de colonização empreendida pelos franceses no Maranhão. 
comunicação com a frente de guerra. No Pará, missionários capuchinhos foram deslocados com grupos de índios Tembé para o rio Capim, a fim de ocupar antigos mocambos - os quilombos de escravos africanos - criando neles aldeamentos indígenas concebidos com a intenção de evitar a formação de novos núcleos de resistência (Palazzollo, 1956; Taubaté e Primério, 1929; Primério, 1937).

Ainda que consideremos os índios aldeados na missão capuchinha uma pequena fração da população indígena total, o alcance do empreendimento foi notável e os números relativos à missão igualmente surpreendentes. Levando em conta os dados apresentados pelos historiadores da Ordem Menor (M. da Nembro, J. Palazzollo, M. Resende de Taubaté e Fidélis Motta Primério) discutíveis por não levarem em consideração fatores como o tempo de duração, a mobilidade da missão católica, as migrações e evasões dos índios, ainda assim o quadro da missão é surpreendente. Ligados à Prefeitura do Rio de Janeiro, isto é, deixando de lado as Prefeituras da Bahia e de Pernambuco, responsáveis pela missão no Nordeste, os frades estiveram atuando, a partir de 1844 , em quase todas as províncias do Brasil, ${ }^{1}$ o que nos leva a observar que parte significativa dos grupos indígenas brasileiros, antes de terem sido investigados pelos primeiros etnólogos no século $\mathrm{XX}$, viveram experiências proporcionadas pela convivência com os capuchinhos e com os funcionários do governo do Império, conheceram o proselitismo católico, o trabalho nas lavouras de grandes proporções ou na abertura de

11. Em São Paulo, a missão capuchinha atuou entre os Guarani (Kaiowá e Ñandeva) no aldeamento de São João Batista da Faxina, sendo que até as primeiras décadas do século XX ocorreu uma série de outras iniciativas catequéticas incidindo especialmente na região dos rios Paranapanema e Verde, com a montagem de aldeamentos no Capão Bonito do Paranapanema e em Surupuí; no Paraná, entre Guarani (Kaiowá, Ñandeva e Mbya) e Kaingang, o sistema de aldeamentos reuniu centenas de índios em cinco aldeamentos. São Pedro de Alcântara sozinho chegou a contar com uma população de mais de 1000 pessoas, entre índios, negros, africanos c brancos; no Mato Grosso, os capuchinhos aldearam os Quiniquináu, Terena e Guaná, além de terem mantido uma missão nos Kadiwéu; em Itambacuri, Minas Gerais, a missão reuniu os Botocudo, Pojixá, Nacnenuc, Maxakali, Poté e Patachó; no Espírito Santo, foram mantidos aldeamentos entre os Botocudo e os Puri; em Goiás, a missão nos rios Tocantins e Araguaia atuou entre os Krahó e os Apinayé; no rio das Mortes foram aldeados os Xavante. Xerente e Canoeiro juntamente com brancos; no Pará, os capuchinhos atuaram em Itaituba e mantiveram por dez anos o aldeamento do Bacabal, entre os Mundurucú. A partir da década de 1855, foram montadas missões no rio Amazonas, nos rios Uaupés e Içana, e no rio Japurá. Banco de Dados Missões Capuchinhas do Império - CEBRAP, 2002. 
istratas ou na navegação dos rios. Experimentaram a escolarização e estiveram expostos ao contágio de epidemias.

\section{Conquista do paladar}

Já se disse que os mecanismos civilizatórios do período do Império objetivavam a "ocidentalização do corpo" (Ramos, 1998), programa expresso no discurso dos estadistas e que pode ser igualmente observado na práxis missionária. A disseminação dos "alimentos-droga" que acompanha a expansão do sistema mundial foi por sua vez identificada como uma marca peculiar da noção de pessoa cristã, que concebe a criatura humana como algo imperfeito, com necessidades, desejos e que busca o prazer, assim como evitar a dor no consumo diário e generalizado das drogas leves - café, chá, chocolate e açúcar, e das não tão leves - as bebidas destiladas (Sahlins, 1988). Tomando uma perspectiva que observa a situação do contato como o resultado de negociações de parte a parte, mais que da imposição e submissão das populações indígenas, busca-se aqui identificar os mecanismos de sedução da missão cristã nas suas inúmeras tentativas de inserção dessas populações no mercado de trabalho. Recuperar o momento particular que constituiu a missão capuchinha do Império é assim condição indispensável para se esclarecer o sentido e a potência das políticas indígenas no contexto das missões cristãs.

Tal programa cumpria-se por etapas. Iniciava-se com fartas roças, plantadas para servirem de brinde, distribuía-se sal, açúcar e rapadura, aguardente e cigarros. Os mecanismos da civilização cristã visavam a mudança de hábitos da população indígena e processavam-se por meio do paladar, operação que se completava em uma segunda etapa, com a distribuição de roupas e ferramentas. Na década de 1840, o Barão de Antonina enviava ao Governo de São Paulo seu plano para a redução dos Kaiowá do rio Verde, que consistia das seguintes etapas:

(...) criar entre os índios as necessidades do homem civilizado, facilitando-lhes para isso os meios necessários. Escolher no sertão terras boas e devolutas e ali principiar uma espécie de aldeamento junto à qual se mandariam fazer roças grandes para o mantimento por três ou mais anos à custa dos cofres públicos; fonecer ferramentas e vestuário todos 


\section{MARTA AMOROSO}

os anos para que a certeza dos bens os obrigasse a fixá-los. Logo no início seria necessário ensiná-los a criar porcos, aves e mesmo dar-lhes algum gado, se mostrarem desejo de o possuir. Seria, depois de acostumados, impossível voltar à vida errante (Barão de Antonina, 1848: 7-42; 376-400).

As roças de milho e feijão vinham acompanhadas de outros itens apresentados aos índios com fins sedutores: sal, açúcar, carne de animais domésticos (gado bovino e porcos), rapadura, aguardente, fornecidos inicialmente na forma de brinde. Em 1845, Frei Pacífico de Montefalco, do aldeamento de São João Batista da Faxina, viajando com o Barão de Antonina, chegava até os Kaiowá do rio Verde. Identificando no paladar a porta de entrada da civilização cristã, os agentes civilizadores distribuem fumo, aguardente, sal, rapadura e açúcar. Acostumar o paladar do índio ao gosto doce, salgado e ardente da civilização era o primeiro passo e principal ardil da manutenção dos índios aproximados, ainda que a contragosto, dos equipamentos coloniais: as remessas de sal, sistematicamente encaminhadas ao aldeamento de São Pedro de Alcântara, no Paraná, eram, segundo seu diretor, o que garantia os indios aproximados dos aldeamentos e o que motivava os índios do sertão a visitar as colônias do governo. ${ }^{12} \mathrm{O}$ sal será o único item alimentar que permaneceu sendo doado aos índios pela missão capuchinha, com o mercúrio para curar as feridas e as ferramentas para o trabalho na lavoura, tudo mais deveria ser adquirido com o trabalho. Nos aldeamentos de São Pedro de Alcântara e Sĩo Jerônimo, núcleo onde a missão teve maior fôlego, a capacidade do sistema de fornecer esses itens foi o medidor do sucesso da missão.

A presença dos civilizados correspondia ao terceiro elemento do programa civilizatório. A missão capuchinha apoiava-se fortemente na idéia do "exemplo edificante" que a "gente morigerada e trabalhadora" podia dar ao indio. O convívio com o trabalhador cristão era considerado elemento central

12. "(...) o maior gasto de sal é para com os índios, não só aldeados como os do sertão, tanto Kaiowás como Guaranis e Coroados. Assim como sem o sal não se pode nestes climas ter consigo os animais irracionais domésticos, assim sem o sal seria impossível cuidar-se da catequese, e civilização dos índios, porque se enquanto selvagens passam bem sem ele, por não o conhecer, ou não poder possuir, logo porém que a ele se acostumam, criam dele uma necessidade indispensável, vêm-se obrigados mesmo a seu mal grado, a nos rodearem e viverem conosco, para dado ou vendido obterem o sal, do qual sem ter, ser-lhe-ia a falta, comprometer-lhe-ia a existência". Curitiba. DEAPP. Ms. Oficio de Frei Timotheo de Castelnovo ao Presidente da Província do Paraná, 15/05/1878. 


\section{CONQUISTA DO PALADAR}

da calleytuese e civilização: quer por meio dos casamentos interétnicos, quer pror meio da utilização da mão-de-obra indígena na produção da subsistênciil, o projeto de povoamento e colonização investia na dissolução física e identitúria dos índios no meio civilizado. Toda uma política de distribuição de terras a colonos foi ensaiada pelos missionários, favoráveis à liberalização dos terrenos devolutos dos aldeamentos para os colonos brasileiros, por meio de doações ou por venda a preços módicos. É do Frei Serafim de Gorízia, fundador da cidade de Itambacurí, Minas Gerais, antigo aldeamento Botocudo e Pojitchá, uma boa síntese da meta da política indigenista do período:

E tem sido justamente em virtude desta união e aliança entre lavradores indigenas com lavradores nacionais que se tem conseguido aqui a mais acertada e espontânea transformação dos selvagens prejudiciais em laboriosos nacionais mestiços, desaparecendo de um modo imperceptivel pela mesma metamorfose, ou por morte natural, o alto algarismo de índios puros, terror dos habitantes desta fértil região (Palazzollo, 1973: 174).

Ponto polêmico no universo missionário cristão, o caráter misto da missão capuchinha institucionalizado no século XIX contrastava com a tradição missionária jesuítica (Jean Lacouture, 1933) e foi, por vezes, questionado pelos missionários da Ordem Menor como uma forma violenta de sociabilidade. Na prática, a defesa da migração e imigração estrangeira como meio de se acelerar o processo aculturativo dos índios figurava como uma declaração de impotência da missão católica no cumprimento do programa de catequese e civilização dos índios. No Paraná, depois de quatro décadas de missão, os Guarani e os Kaingang permaneciam prestigiando os aldeamentos na exata proporção que a função provedora dessas instituições se cumpria. Com o passar dos anos, os índios aldeados tornavam-se mais exigentes, não dando, no entanto, sinais de submissão ao projeto cristão:

Aqui neste aldeamento (São Pedro de Alcântara) luta-se com todas as dificuldades invencíveis para satisfazer as exigências dos índios. Trazem suas ferramentas e outros utensílios de sua lavoura para consertar, e se não se tem materiais para o conserto, voltam os índios aos seus domínios descontentes e nada dispostos a persuadirem-se que não se tem. ${ }^{13}$

13. Curitiba. DEAPP. Ms. Oficio de Frei Mariano de Bagnaia ao Presidente da Província do Paraná, $01 / 11 / 1886$. 


\section{MARTA AMOROSO}

A proximidade dos brancos, por sua vez, não representava mudanças significativas nos hábitos dos Kaingang e dos Guarani, e mesmo os casamentos interétnicos, aos quais se creditava grande poder aculturativo, aconteciam em escala insignificante nos aldeamentos. A eficácia da proximidade dos não-índios na erradicação do problema do índio selvagem se dava, isso sim, pelo contágio de epidemias, das quais a população indígena não escapava. Comentando as dificuldades que a missão cristã enfrentava na implementação de seu programa aculturativo, Frei Timotheo condensava em uma frase o que aprendera no Brasil sobre os índios: "(...) os índios serão índios, enquanto não mudarem o sangue pelas misturas das raças ou se extinguirem pelas doenças, e pestes". ${ }^{14}$

As representações coloniais sobre os mecanismos para a civilização dos índios - sedução, sedentarização, trabalho e conversão - estágios a que se seguia a recomendação de extinção dos equipamentos do governo, não encontraram, assim, correspondência na vida em aldeamento. As etapas jamais se sucederam da forma prescrita pelos administradores; no entanto, nos auxiliam a identificar os meios da sedução: a civilização chegou aos Xocleng na forma de cigarros e roças; ${ }^{15}$ aos Guarani, Kaiowá e Kaingang na forma de açúcar, aguardente e rapadura. O sal e outras mercadorias dos civilizados atraíam e mantinham aproximados os índios, mas não necessariamente operavam-se as mudanças almejadas pelos administradores. Do ponto de vista das populações indigenas aldeadas, uma série de inconvenientes da vida em aldeamento falava mais alto porque ameaçava a integridade dos parentes, a segurança das mulheres e das crianças, justificando a manutenção por parte dos índios de cuidadosa distância da sede dos aldeamentos. ${ }^{16}$ Uma resistência muda que, no entanto,

14. Curitiba. DEAPP. Ms. Oficio de Frei Timotheo de Castelnovo ao Presidente da Província do Paraná, 10/01/1889.

15. Sobre as tentativas frustradas de redução dos Xokleng no aldeamento de São Tomás da Papanduva, ver Curitiba. DEAPP. Ms. Oficio de J. F. Lopes ao Presidente da Província do Paraná, 20/08/1877.

16. É o que comenta Frei Timotheo: "Este aldeamento (São Pedro de Alcântara) apesar da mais escrupulosa vigilância da minha parte deixa de ter ressentido algum inconveniente cin que toca a moral; todos sabem que os índios Cayoás são zelosos em extremo das suas mulheres, basta qualquer imprudência a este respeito para os desconfiar e até afugentá-los, e consta-me que nas primeiras diligências que o Sr. Barão de Antonina empregou para conduzir estes índios de além Paraná para o Jataí, que uma condução inteira foi perdida pela imprudência de um camarada, e mesmo depois da minha chegada pela má vontade de uns trabalhadores no Jataí, afugentarem 


\section{CONQUISTA DO PALADAR}

jamais prescindiu dos bens e da tecnologia dos civilizados, se processava em torno dos aldeamentos indígenas. ${ }^{17}$

\section{Para além das cidadelas cristãs}

Destacam-se, nesta segunda parte do texto, a reflexão, o movimento e a disposição espacial dos grupos Kaingang e Guarani nos aldeamentos do Paraná e São Paulo, tomando como referência o caráter sistêmico dos equipamentos missionários. Passa-se a seguir à observação da planta urbanística do aldeamento de São Pedro de Alcântara, núcleo do sistema missionário da região, para nela identificar o lugar que as populaçōes indígenas ocupavam naquela missão. Retomemos para tanto o episódio da epidemia de varíola que flagelou os Kaiowá aldeados em São Pedro de Alcântara em 1877, e que foi tema da Exposição Antropológica de 1882.

Na manhã do dia 8 de janeiro de 1877, Frei Timotheo de Castelnovo constatou pessoalmente que a varíola, doença que sabia ser epidêmica e mortal para os índios, atingira as aldeias dos Kaiowá ao norte da sede da missão. Em poucos dias, somou-se mais de 400 mortos e o aldeamento de São Pedro de Alcântara, originalmente um núcleo Guarani (formado pelos

em um só dia mais de 90 índios. Estes fatos teriam deixado em silêncio se não fosse para mostrar como é incerta a opinião daqueles que pensam que desde a chegada dos índios das suas matas devem ser entremeados com a gente civilizada. Seria inteiramente malograda a catequese dos indígenas se o missionário Diretor não fizesse todas as diligências de evitar este mal, e se o governo toda a coadju varão necessária”. Rio de Janeiro. BNRJ. Ms. Relatório de Frei Timotheo de Castelnovo, Ofício de José A. Vaz de Carvalhaes, Vice Presidente da Província do Paraná ao Conselheiro Luiz Pedreira do Couto Ferraz. Paraná, 10/02/1857.

17. Durante o período focalizado observaremos a ética alimentar tradicional das populações indígenas colocando sérias restrições ao consumo de determinados itens da cultura ocidental, como por exemplo, a carne de gado, que era oferecida inicialmente como brinde. Em 1859, ano da aproximação dos Kaingang do sistema de aldeamentos, Frei Timotheo registrou que os guerreiros que abordaram São Pedro de Alcântara mataram alguns bois do aldeamento, desprezando sua carne. Da mesma forma os Kaiowá e Guarani vinculavam a força dos poderes mágicos da Xamã ao rigor de sua dieta, na qual não poderia constar nenhum produto dos civilizados. Os Apapocuva que viveram por um tempo no aldeamento de São Pedro de Alcântara atribuíram a força de Guyracambi, seu principal líder religioso, ao fato do cacique alimentar-se exclusivamente de mel, caça e canjica, seguindo os costumes dos antepassados (Nimuendajú, 1950: 29). 
Kaiowá trazidos em 1850 do Mato Grosso e pelos Nandeva), lastimou a morte ou o abandono pela fuga para o sertão de antigos aliados com os quais conviveu durante duas décadas. No seu português truncado, o missionário comentava a calamidade:

\begin{abstract}
Não tem outro remédio, senão humildes e resignados abaixarmo-nos a cabeça, e adorar os decretos da empresa da Divina Providência. Pois de quanta aflição não se enche nosso coração em vermos nós perecerem tantas pobres gentes de nos amados, e talvez perdidos os frutos de vinte e mais anos de sacrifício, cuidados e despesas. Seja tudo pelo amor de Deus. Como se a luta do dia 14 de setembro próximo palssado havida entre os Índios Coroados, neste Aldeamento. As bexigas aqui casualmente importadas, e casualmente introduzidas entre os Índios Caiguás; talvez me acabe pura sempre também esta missão. E tanto mais deve-se sentir enquanto estes Índios tem prestado tanto serviço mesmo ao estado e aos povos, e são tão pacíficos, serviçais, e úteis. ${ }^{18}$
\end{abstract}

Na época, São Pedro de Alcântara reunia os Kaingang e os Guarani, além de missionários, funcionários administrativos, militares, colonos, comerciantes e africanos livres. Tomando como referência as populações indígenas aldeadas, constatamos primeiramente que os grupos Kaingang e Guarani permaneceram espacialmente separados em situação de aldeamento, criando dinâmicas diferenciadas de contato com a missão. Para tanto, é preciso observar a missão capuchinha como instituição complexa, disposta a atuar em um amplo território de forma articulada, o que nos leva a uma abordagem dos aldeamentos indígenas como um sistema constituído por múltiplos centros de ação. A epidemia de $1877^{19}$ que ameaçou dizimar os Kaiowá - assim como outros eventos da história do aldeamento, como conflitos intertribais e interétnicos - revelavam que o território da missão era delimitado por etnia e por grupo social. Constata-se que as fronteiras criadas

18. Curitiba. DEAPP. Ms. Oficio de Frei Timotheo de Castelnovo ao Presidente da Província do Paraná, 16/12/1885.

19. A epidemia de 1877 em São Pedro de Alcântara fora trazida por um morador da Colônia Militar do Jataí, que contraíra a doença na Vila do Tibagi. Na versão de Frei Timotheo, um apelo pessoal do missionário ao diretor da Colônia Militar fizera que o doente fosse isolado para tratamento em um paiol de milho abandonado, pertencente a um particular. A medida visava proteger os índios do contágio. Logo que o doente se curou, o paiol, que ficava na margem direita do rio Tibagi, em frente a uma das aldeias dos Kaiowá, foi invadido por estes índios e o milho contaminado ali depositado foi consumido pelos índios, que contraíram a doença. Em 


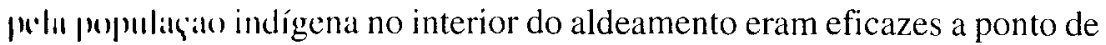
firrantir que os Kaingang aldeados e os brancos que habitavam a Colônia Militar do Jataí na outra margem do rio saíssem ilesos de uma epidemia que atingiu os Kaiowá.

A idéia de um sistema de aldeamentos indígenas articulados não estava ainda clara no Decreto de 1845 , da "Catequese e Civilização", regimento mais atento para os cargos, atribuições e salários de seus funcionários. Aparecia, no entanto, de forma bastante explícita no Regulamento das colônias indígenas do Mato Grosso e Paraná, de 1857, que formalizava o conceito de um sistema de aldeamentos e colônias do governo articuladas com o objetivo de "drenar" os índios de uma vasta região, assentando-os em aldeamentos fixos. Na região dos rios Paranapanema e Tibagi foram criados cinco aldeamentos: além de São Pedro de Alcântara, o núcleo central da operação, funcionaram os aldeamentos de São Jerônimo, Pirapó, Santo Inácio e Faxina (em São Paulo). Inicialmente, dispunham-se alguns núcleos, por região, que eram gradativamente desativados até restar um único aldeamento concentrando diferentes etnias. O governo, ao dispor os aldeamentos nas províncias, atendia demandas claras impostas pela necessidade de comunicação do governo do Império com o sertão. Núcleos eram implantados em pontos estratégicos com a dupla função de um lado de sedentarizar, catequizar e civilizar os índios e, de outro, de promover a ocupação do sertão, obtendo, por meio da utilização da mão-de-obra indígena na abertura de estradas e na limpeza, áreas que possibilitavam o acesso do colono nacional ou estrangeiro às terras cultiváveis.

Se esse era o programa da política pública da época, na prática as coisas se davam de forma diferenciada. De fato, observa-se que, sob o impulso

poucos dias, cinco índios haviam morrido, e da primeira aldeia Kaiowá atingida pela doença todos fugiram para o sertão. Frei Timotheo criou então na área Kaiowá um "lazareto", um hospital para isolar e tratar dos doentes, e contrattou duas pessoas que já haviam sido curadas da varíola, para cuidarem dos Kajowá. A providência de nada valeu. Entre os dias 8 e 14 de janeiro todos os homens adultos da aldeia kaiowá estavam mortos; o hospital foi abandonado, tendo os doentes fugido em seis canoas, no meio da noite, pelo rio Tibagi. A direção do aldeamento conseguiu, então, como medida preventiva, vacinar os Kaingang aldeados ao sul da sede. Estes escaparam ilesos, assim como os moradores não-índios de São Pedro de Alcântara e os moradores da Colônia Militar do Jataí. Aos Kaiowá não era recomendável a vacinação, já que a doença havia se desenvolvido entre eles, condição na qual a inoculação do vírus aceleraria ainda mais sua manifestação. 
da missão, dos seus equipamentos e da tecnologia, o território ocupado pelas etnias sofria alterações profundas e, ainda que isso não ocorresse nos moldes prescritos pelas autoridades, a chegada da missão definia novas regras. Para entender tal dinâmica é preciso superar o senso comum da missão identificada com um grupo fixo - e imóvel - de índios aldeados: houve grande circulação da população indígena em torno dos aldeamentos capuchinhos da região de São Paulo e Paraná. Um caso ocorrido no aldeamento de São João Batista da Faxina nos auxilia a compreender essa dinâmica imposta pelos índios aos aldeamentos.

Em 1847, o governo imperial fornecia a São Paulo uma interpretação da lei da "Catequese e Civilização" que indicava que a tutela dos índios cumpria ciclos determinados, ao final dos quais os aldeamentos deviam ser extintos. ${ }^{20}$ As verbas governamentais deslocavam-se constantemente para atender novas urgências, demandadas pelos governos das províncias, o que na maioria das vezes se fazia às custas da desmontagem de núcleos antigos. Tendo diante de si o problema das "hordas de selvagens errantes", para o qual a solução da catequese se aplicava, a questão dos índios domesticados, lavradores, confundidos com a população geral deixava de ser atribuição do Estado. O governo imperial esgotava o compromisso da tutela dos índios quando dava por cumprido o projeto de civilização. No entanto, desativar o aldeamento não significava, necessariamente, ter o índio integrado à sociedade nacional como previam os legisladores, mas, sim, que a população daquele aldeamento poderia ter se deslocado para outro núcleo de catequese

20. "Sendo o principal frm do Regulamento n 926 de 24 de junho de 1845 arrancar à vida errante a multidão de selvagens que vaga pelos nossos bosques e para reuni-los em sociedade, inspirar-lhes o amor ao trabalho, e proporcionar-lhes os cômodos da vida civil, até que possam apreciar as suas vantagens, e viver de qualquer trabalho, ou indústria, e sendo para esse fim autorizada a criação de novas aldeias, e a respeito dos Índios, que nelas residam, ou dos que tirados dos bosques, precisem ser aldeados. E porque consta que, mal entendido por alguns Diretores-Gerais a citado Regulamento, têm eles procurado aldear alguns índios e seus descendentes, que há muito vivem sobre si confundidos na massa geral da população, constrangendo-os desta sorte a uma cspécie de tutela, de que já não carecem, e que portanto não-lhes pode ser imposta, por ser isto contrário a benéfica intenção com que foram decretadas as providências do dito Regulamento: manda outro sim o mesno Augusto Senhor que a dar-se na Providência, à que V. Exa. preside, este ou qualquer outro semelhante abuso, cuide desde logo V.Exa. em extirpá-lo, advertindo ao respectivo DiretorGeral para que se contenha na órbita de suas atribuições”. São Paulo. AESP. Ms. Palácio do Rio de Janeiro ao Presidente da Província de São Paulo, 24/08/1847. 
c cle civilização mais bem provido, mais seguro, exclusivo da etnia. ${ }^{21} \mathrm{O}$ índio não se dissolvia na população regional, simplesmente rumava com seu grupo para outro aldeamento.

Em 1862, o missionário capuchinho de Faxina, Frei Pacífico de Montefalco, enviava uma denúncia ao Governo, ${ }^{22}$ na qual revelava que os Kaiowá estavam manipulando o programa de catequese e civilização dos índios, fingindo-se selvagens, quando eram velhos conhecidos da missão católica, ex-catecúmenos casados e batizados nos aldeamentos capuchinhos de São Paulo e Paraná. A denúncia de Frei Pacífico se fazia no contexto da abertura de novos aldeamentos indígenas no rio Paranapanema e no Paraná, para os quais a verba para a "Catequese e Civilização" dos índios de São Paulo estava sendo canalizada. Frei Pacífico acusava o governo de oferecer tratamento diferenciado aos aldeamentos indígenas e de desprestigiar a missão colocada sob sua direção, em comparação com as novas missões do Paraná, ou aquelas que se criava, então, na margem paulista do rio Paranapanema. O desabafo do frade, além de confirmar a economia do "lençol curto" na qual eram mantidos os aldeamentos e as colônias indígenas, continha elementos substanciais para a compreensão do uso que as populações indígenas dava ao sistema de aldeamentos da região do Paraná, São Paulo e Mato Grosso.

Os índios circulavam em torno dos aldeamentos, seguindo o compasso das verbas que eram encaminhadas para uma ou outra unidade do sistema. Quando necessário, lançavam mão de recursos teatrais, como o utilizado pelos Kaiowá de Faxina, que se apresentaram pintados no gabinete do Presidente da Província de São Paulo, na década de 1860, mostrando estarem afinados com as regras da política indigenista da época, que pregava que verbas públicas exigiam índios selvagens. Dizia Frei Pacífico:

21. O missionário de São Pedro de Alcântara registrou este fenômeno no Paraná, quando observou em diferentes ocasiōes aumentar o número de índios do aldeamento em decorrência da extinção de outros núcleos. É o que vemos, por exemplo, quando afirma "a povoação indígena não poderia ser de novo espalhada sem comprometer a Província; que as dificuldades crescem com o aumento dos índios que para ele (São Pedro de Atcîntara) afluem vindos dos já extintos aldeamentos(...)". Curitiba. DEAPP. Ms. Oficio de Frei Timotheo de Castetnovo ao Presidente da Provincia, 1881.

22. São Paulo. AESP. Ms. Oficio de Fr. Pacífico de Montefalco, Vice-Prefeito dos Missionários Capuchinhos para D. Diretor-Geral dos Índios, José Joaquim Machado de Oliveira. Aldeamento de S. João Baptista, 20/07/1862. 


\section{MARTA AMOROSO}

Os índios que moram no Salto-Grande em parte são deste aldeamento, e parte são daqueles que vieram do Jataí em 1852, os quais sâo todos batizados, e casados em parte. Aqueles que são deste aldeamento. o Capitão deles é um índio chamado José de Camargo, o qual é nascido, batizado, e casado neste aldeamento, e o ano passado foi apresentado com outros Capitães dos sobreditos do Jataí a essa Presidência como bravos, que bela especulação!!! E lá para essa Cidade até ficaram pintados. Eu tenho mandado Índios de minha confiança ao tal Salto-Grande, para ver, especular o que eles lá fazem, e o que o Governo the dissera. Os próprios contaram-me que aqui em S. João (Batista da Faxina), o Governo não dá coisa alguma à vista dos de lá, e quando (estes) vão em São Paulo V.Exa. e o Governo dizem a eles voltem para S. João arranjem-se com o vosso Padre. e no Salto-Grande o Governo dá ferramenta, roupas, cspingarda, rosários. Eles sabem que em S. Jerônimo (Paraná), Jataí, Pirapó, o Governo dá tudo o que é de absoluta necessidade, e que por isso lá tem assalariados escravos da Nação. E roupa [ ], e até correio. Eles sabem que a Assembléia Presidencial orça todos os anos uma quota para eles, porém aqui em $\mathrm{S}$. João fala-se só de promessas, e nada vem, passa um ano, passa outro e assim todos os anos vão em promessas, c para essas promessas nunca chega o dia desejado. ${ }^{23}$

Os Kaiowá em questão haviam migrado do Mato Grosso para o Porto do Jataí na década de 1850. Diante das condições encontradas no entreposto do Barão de Antonina e das dificuldades de dividir o território do aldeamento com outra liderança Kaiowá - ligadas ao cacique Libânio - dirigiram-se para Faxina, São Paulo, ${ }^{24}$ sendo também aí rejeitados pelos Kaiowá que ocupavam aquela missão. Este grupo partirá então para a região do Paranapanema paulista, onde será montado na década de 1860 o aldeamento de Tijuco Preto, no qual atuou o missionário capuchinho Frei José de Loro. ${ }^{25}$

23. São Paulo. AESP. Ms. Ofícios recebidos. Presidente dá Província, 20/07/1862.

24. " ...existe reconhecida inimizade entre o Capitão José, chefe da tribo a que V. Exa. se refere, e o Capitão Libânio, chefe da que reside no Jatá, tomando essas indisposições muito difíceis senão impossivel a reunião das duas tribos em um mesmo aldeamento". Ofício do Presidente da Província do Paraná dirigido ao Governo de São Paulo, no qual este solicita a retirada dos Kaiowá do Jataí do aldeamento de São João Batista da Faxina. São Paulo. AESP. Ms. 25/10/1855.

25. Frei José de Loro, por sua vez, teve um itinerário não menos instável: esteve em São Pedro de Alcântara, no Paraná, onde se indispôs com Frei Timotheo. Seguiu para o Paranapanema, não conseguindo manter por muito tempo a missão entre os Kaiowá. Foi então para o Maranhão, atuando no aldeamento de Dois Braços, entre os índios Guajajara, onde no início do século XX mais de uma dezena de missionários capuchinhos foram mortos pelos índios. Frei José de Loro morreu de febre amarela em 1884 na missão no rio Grajaú, Maranhão. 
Sobre o funcionamento dessas unidades de "Catequese e Civilização", a atenção que vem se dando à organização social dos aldeamentos tende a questionar conclusões apressadas formuladas pela antropologia do contato na década de 1970. Trabalhos como os de Darcy Ribeiro 1996 [1970] e Carlos Moreira Neto (1971), que haviam dado um tratamento bastante superficial à documentação do século XIX, produziram uma interpretação do período repleta de imprecisões. Nela, os aldeamentos capuchinhos figuravam como instituições falidas, que não teriam causado impacto sobre a população indígena, por constituírem experiências fugazes, das quais os índios mantiveram-se afastados. A situação criada no Paraná depois da entrada em funcionamento do sistema de aldeamentos ou colônias indígenas, modificando integralmente a forma de ocupação do território da Província pela população indígena, desmente em parte tais afirmações, no que diz respeito ao tempo de duração e impacto dos estabelecimentos do Império. Se tomarmos a missão cristã entre os índios como ponta de lança da política expansionista de uma época (Comaroff e Comaroff, 1991), podemos repetir sem maiores ajustes para o século XIX a máxima formulada sobre a Amazônia colonial pelo historiador João Lúcio de Azevedo (1901). Dizia ele: "cada um desses marcos, que era a missão, constituía até novo avanço, a divisória do mundo policiado com o selvagem. E a fronteira assim delineada, jamais recuou..."

Quanto ao grau de distanciamento que a população indígena manteve dos aldeamentos, é preciso considerar que tal distância longe de invalidar a análise antropológica, constitui seu ponto de partida. Se a evasão foi um fato, testemunhado pelos missionários capuchinhos e demais agentes, é temerário desprezar o impacto dos aldeamentos católicos na população indígena do século XIX. A evasão dos índios foi tão verdadeira quanto a presença dos Kaingang, Kaiowá e Guarani no sistema de aldeamentos criados no Paraná. Tal presença, em certos casos, prefigura situações de extrema atualidade, como no caso de São Jerônimo, posto ocupado desde o momento do assalto dos Coroados em 1859 e mantido até hoje pelos Kaingang, tendo sido gradativamente encampado pelo grupo como espaço de uso exclusivo dos índios. ${ }^{26}$

26. Neste sentido, a presença dos Kaingang, no século XIX, nos aldeamentos indígenas do norte do Paraná, pode ser interpretada como um caso de contato desencadeado pelos próprios índios, semelhante ao descrito por Turner para os Kayapó (1979: 8). Para o século XX, etnologia irá registrar situações de constrangimento efetivo dos grupos kaingang diante da expansão da 
Diante do sistema de aldeamentos, uma série de questões se coloca. Qual a importância dos equipamentos do governo no contexto das disputas interétnicas e interfaccionais? No plano das relações sociais e políticas com a sociedade nacional, quais as dimensões da tutela do governo imperial, que pôde por vezes significar a defesa - individual ou coletiva - da causa indígena nos confrontos com colonos e fazendeiros? É preciso, dessa forma, partir para uma qualificação da territorialidade indígena depois da implantação dos aldeamentos, o que buscaremos fazer utilizando os recursos da análise multilocal (Sahlins, 1997), que permite observar como as populações indígenas aproximaram-se e mantiveram-se articuladas ao sistema de aldeamentos, desenvolvendo aí formas de uso compatíveis com a nova realidade do contato e de convivência com a sociedade envolvente sem, no entanto, abandonarem formas tradicionais de sociabilidade. Toma-se, assim, um partido de análise que prioriza o acompanhamento do processo gradativo de apropriação e ressignificação das instituições ocidentais pelos índios, podendo o observador perceber a dinâmica que vai da disputa pelo controle do espaço do aldeamento - que se dá no interior dos grupos e entre as diferentes etnias - à conquista dos equipamentos produtivos e da tecnologia pela população indígena.

A prioridade, quando não exclusividade, do tratamento da sede administrativa dos aldeamentos compreendida como a sua totalidade tem gerado análises parciais comprometidas com o discurso auto-referido da missão católica. Nota-se uma tendência ao obscurecimento da presença da população indígena, que deixa de ser considerada como agente de processos sociais, políticos e econômicos. Os índios entram em cena apenas como protagonistas do "teatro da conversão" dirigido pelos padres missionários, teatro este que seria o modelo e o padrão de toda missão ou aldeamento. ${ }^{27} \mathrm{~A}$ agência dos missionários, focalizada a partir da sede administrativa da missão, ganha destaque, assim como todo seu aparato de culto, o que é feito em detrimento do protagonismo dos índios no território da missão.

sociedade nacional. Notar que tal constrangimento histórico não chega a alterar a forma particular de aproveitamento do espaço tutelar dos grupos Kaingang e Guarani: o sistema intertribal em Mangueirinha apresenta o mesmo aspecto descrito para o século XIX das habitações Guarani distantes 15 kilômetros do Posto da FUNAI, estando os Kaingang residindo próximos da sede.

27. A idéia do teatro da conversão está, por exemplo, em Luis Felipe Baeta Neves: “(...) é importante lembrar que o teatro foi uma forma de construir um espelho destruidor das culturas indígenas que, em tais peças, apareciam identificadas ao Mal" (1978:83). 
Iissc (ịpo de análise pode ser identificado tanto em relação à missão |csulliı $\mathbf{1 1 0}$ período colonial como aos aldeamentos indígenas do Império. Nola, a sede do aldeamento - parte do complexo urbanístico de tais cmpreendimentos - é tratada como o todo, sinalizando procedimentos de análise que focalizam o local da administração da missão em detrimento dos locais onde se desenrolam as ações dos grupos aldeados. É o que vemos, por exemplo, na análise que Clara E. Monteiro de Barros (1995) realiza da iconografia do aldeamento capuchinho de São Fidélis, Rio de Janeiro, de 1782. Desconsiderando o fato que os índios aldeados não poderiam estar contabilizados em um plano urbanístico que contava com um total de cinco casas anexas à Igreja, a autora deixa, simplesmente, de considerar em sua análise qual seria então o espaço reservado aos índios.

A planta do aldeamento de São Pedro de Alcântara, considerada na sua totalidade, indica diferentes centros - representados pela sede administrativa do aldeamento e pelas aldeias de índios agregados. Da mesma forma, São Jerônimo, outro aldeamento do sistema, não se reduzia à sede administrativa, havendo que se considerar uma disposição espacial mais ampla, que englobava os assentamentos ao longo do rio Tibagi utilizados pelos Kaingang ligados ao aldeamento, distantes algumas léguas da sede da missão, os índios agregados e os índios do sertão, categorias sempre presentes nos aldeamentos do norte do Paraná. A população indígena, via de regra, não estava na sede dos aldeamentos, mas sim em aldeias anexas, onde mantinha hábitos de subsistência e formas de organização sociopolíticas bastante tradicionais. A disposição do espaço dos aldeamentos surgia assim como resultado de negociações de parte a parte, nas quais as lideranças indígenas aldeadas tinham importante papel.

O plano urbano do aldeamento de São Pedro de Alcântara revelava menos controle e imposição de normas dos missionários sobre os aldeados que negociações e respeito mútuo a fronteiras erguidas no interior do aldeamento. Em 1881, Frei Timotheo comentava em relatório oficial sobre a virtualidade do poder do diretor do aldeamento sobre as aldeias de índios:

Os índios vivem cada uns nas suas lavouras, separados, ocupando um terreno de seis léguas em quadra, governados pelos respectivos caciques. Uni-los além de perigoso, seria impossível, estante a diversidade das tribos, e rivalidade entre os das mesmas. ${ }^{28}$

28. Curitiba. DEAPP. Ms. Oficio de Frei Timotheo de Castelnovo ao Presidente da Província do Paraná, $31 / 12 / 1881$ 
A afirmação do missionário aludia ao fato dos grupos indígenas contarem com grande independência em relação à sede administrativa da missão, até pelo ambiente em que viviam, onde ocupavam extensa área que incluía acampamentos de caça, de pesca, aldeias indígenas distantes da missão e, agora, os equipamentos do governo central. A influência das políticas indígenas nos aldeamentos, por sua vez, era de tal ordem que os missionários levavam em consideração as alianças e as oposições entre as facções kaingang na resolução dos conflitos que eclodiam nos aldeamentos.

Do ponto de vista da direção do aldeamento, tratava-se, portanto de uma administração virtual dos índios: a população indígena aldeada, isto é, batizada, casada, contabilizada nos censos da missão e medida em sua produtividade, habitava a uma distância de até trinta léguas do "centro urbano" de São Pedro de Alcântara. Plantava e produzia em suas aldeias, onde mantinha roças para o consumo separadas das plantações extensivas de cana-de-açúcar que alimentavam as atividades econômicas dos aldeamentos. Na época das grandes colheitas, os aldeamentos recebiam visitas dos toldos kaingang do sul (Borba, 1908). Tal comensalidade condenou muitas vezes ao fracasso os projetos dos missionários de criar estoques de mantimentos. A vida em aldeamento só podia ser pensada, assim, como parte integrante de um sistema maior, que incluía as redes de sociabilidade dos Kaingang, de um lado, e dos Guarani, de outro.

A disposição espacial das populações indígenas, afastadas da sede da missão, mantendo grande autonomia, foi notada também nas reduções jesuítas de Guairá. Bartolomeu Meliá (1990: 43) refere-se, por exemplo, aos "povoadozinhos" dos Guarani aldeados, unidades caracterizadas por casas comunais com seus pátios e roças, onde a população mantinha padrões sociopolíticos tradicionais. Citando Montoya, o autor descreveu a disposição espacial dos Guarani nas reduções jesuíticas, relato no qual podemos notar a descentralidade da sede administrativa da missão católica em relação à população indígena:

Os índios estão vivendo a sua antiga usança em matas, serras e vales, em escondidos arroios, em três, quatro ou seis casas sozinhas, separadas a légua, duas, três e mais uns dos outros (Montoya, 1892: 29). Na redução jesuítica de Loreto se haviam juntado 
מão menos de trinta e um desses caciques com a sua gente, e na de San Ignácio, 37 (Meliá, 1990: 43).

Algo semelhante se deu quanto à disposição espacial dos Guarani nos aldeamentos do vale do Tibagi no século XIX, o que nos remete imediatamente aos padrões de habitação dos Tupi-Guarani descritos pela etnologia ameríndia (Gallois, 1980, Viveiros de Castro, 1986).

\section{Aldeados, agregados e "índios do sertão"}

Os frades pregavam - sem grande convicção ou rigor - o fim das "perambulações", o abandono de práticas tradicionais como a poligamia e, com mais empenho, o engajamento dos índios nas frentes de trabalho. O cumprimento integral ou parcial do acordo intercultural traçava os planos espaciais e sociais da territorialidade dos aldeamentos, num gradiente que ia do índio considerado aldeado - contabilizado nos censos populacionais, medido em sua produtividade e atendido em serviços e mercadorias, às vezes batizado e casado pelo ritual católico -, ao "índio do sertão", categoria subsidiária ao sistema, que frequientava esporadicamente os aldeamentos em busca de suprimentos. Entre as duas categorias, uma terceira - a dos grupos instalados na bordas dos aldeamentos, que trocavam sistematicamente produtos extrativistas com os moradores dos aldeamentos e recebiam sal e ferramentas. Importante notar que as três categorias mantinham-se fora do chamado "círculo urbano" do aldeamento, a sede do poder colonial. Os índios do sertão e os grupos estabelecidos nas bordas dos aldeamentos não eram considerados e nem se consideravam aldeados. A separação espacial, no entanto, não representava grande diferenciação no que competia a estarem todas as categorias - aldeados, grupos vizinhos e índios do sertão participando de uma mesma rede de relações.

A relação estabelecida pelos grupos Ñandeva com o aldeamento de São Pedro de Alcântara ilustra bem essa dinâmica de proximidade e de afastamento dos Guarani. Os grupos Ñandeva eram tratados como agregados pela direção do aldeamento nas primeiras décadas do período analisado 
(1850-1860). Mantinham habitação permanente no rio das $\operatorname{Cinzas}^{29} \mathrm{e}$ haviam construído uma vereda de comunicação com São Pedro de Alcântara. lireqüentavam então esporadicamente o aldeamento, segundo o diretor, sempre na época das colheitas, mas recusavam-se a trabalhar nas plantações. Só foram considerados aldeados quando na década de 1880 ocuparam terrenos próximos da Colônia Militar do Jatai ${ }^{30}$ e passaram a produzir excedentes comercializáveis (açúcar e milho). Depoimentos recolhidos por Nimuendajú junto aos descendentes dos que viveram a experiência dos aldeamentos capuchinhos agrega algum sentido à evasão dos índios da missão de catequese: segundo o etnólogo alemão, os Ñandeva identificavam os aldeamentos indígenas com as frentes de trabalho dos índios organizadas pelos missionários capuchinhos. Os Apapocuva relataram que haviam se deslocado na década de 1850 da região do rio Iguatemi e caminhado em direção aos rios Paraná e Tibagi. ${ }^{31}$ Receberam então roupas e tecidos e acabaram construindo uma aldeia distante dos brancos e dos negros da

29. "Felizmente os que estão aldeados neste aldeamento são todos Cayuas e Coroados. A tribo Guarani (Ñandeva) pertence um grande toldo existente no rio Ziza (das Cinzas) que seguidamente andam aqui, nessa capital e S.Paulo pedindo gêneros, e que the os damos; mas que julgo melhor serviço à catequese, se se lhe dissesse: "Vós sois moços, sois ladinos, falai bem nossa língua, portanto em lugar de ir sempre pedindo, e ciganeando, ides adquirir o que precisais pelo trabalho, deixando de viverem a custa alheia; mas sim do suor de vosso rosto"'. Curitiba. DEAPP. Ms. Oficio de Frei Timotheo de Castelnovo ao Presidente da Província do Paraná, 30/12/1878. Os Ñandeva e Mbyá constituíam a categoria de índios agregados que visitavam periodicamente os aldeamentos do norte do Paraná. Até a década de 1880 não mantinham habitação permanente nos aldeamentos, compareciam na época das colheitas e na distribuição de brindes. A partir dessa fase passaram a habitar próximos ao aldeamento de São Pedro de Alcântara e da Colônia Militar do Jataí, tornando-se produtores de açúcar para a venda local. Essa população provinha da região dos rios Paranapanema, Cinzas, Laranjeiras e Congonhas.

30. "A população que compõe o aldeamento é a mesma de ano passado e só teve incremento nos índios Guarani, em número de 62 almas, que se esta tribo é da mais vagabunda, e inerte, hoje parece de mudar-se, e querer residir definitivamente, dá-se ao trabalho tem suficiente plantação, e precisa se lhe dar seus elementos indispensáveis”. Curitiba. DEAPP. Ms. Oficio de Frei Timotheo de Castelnovo ao Presidente da Província do Paraná, 31/12/1881.

31. A história do parentesco dos Ñandeva-Apapocuva que articula o grupo de São Paulo, posteriormente etnografado por Nimuendajú, aos primeiros moradores da Colônia Militar do Jataí e do aldeamento indígena de São Pedro de Alcântara, está publicada em Egon Schaden (1953 e 1958). Não consta da monografía clássica do etnólogo alemão As lendas da criação e destruição do mundo como fundamento da religião Apapocuva (1914), ainda que nela ocorram referências esparsas aos aldeamentos capuchinhos do norte do Paraná. Temos aí um exemplo de 
l 'ukinn Militir do Jataí, disposta em frente à missão capuchinha de São l'cileo de Alcântara. Nessa mesma época chegaram, nos aldeamentos do Paraná, os Kaiowá e os missionários que iriam dirigir os equipamentos do Governo. Os Apapocuva lembravam da figura de Frei Timotheo presidindo por longo período a aldeia do Jataí, sempre aconselhando os índios a trabaIhar. O missionário distribuía os trabalhos na lavoura e trouxera para o Tibagi os apetrechos para o fabrico da cachaça e do açúcar. Os Guarani em pouco tempo perceberam que não lhes agradava viver à maneira que lhe propunha o missionário, não queriam tomar café, nem comer carne de gado: "Para quê? Então haveremos de morrer aqui de tanto trabalhar?" Foi quando se deslocaram para o rio Verde, em São Paulo (C. Nimuendajú, 1950:16).

A categoria dos índios aldeados correspondia ao grau máximo de proximidade do aldeamento, vínculo que tinha expressão espacial e econômica: os índios aldeados eram aqueles que mantinham habitação permanente junto ao aldeamento e participavam da sua vida produtiva e comercial. Uma análise dos quadros da produtividade do aldeamento (M. Amoroso 1998a), contabilidade minuciosamente registrada pelo missionário ao longo de quarenta anos de funcionamento da destilaria que montara com os índios, confirma que os Kaiowá e Kaingang - e a partir da década de 1880 os Ñandeva - participavam do sistema produtivo e comercial de São Pedro de Alcântara, ilustrando a categoria de índios aldeados. A indústria dos índios era gerenciada pelo capuchinho e intermediada pelos comerciantes instalados na Colônia Militar de Jataí. Veremos que a destilaria de aguardente de São Pedro de Alcântara, colocada em funcionamento na década de $1860 \mathrm{e}$ em operação até o final do período estudado, em 1895, representou o centro da vida social do aldeamento, ponto de convergência dos múltiplos interesses daquela sociedade plural, onde as fronteiras internas marcavam universos sociais totalmente distintos. Em torno de um alambique de aguardente, centenas de índios Kaiowá e Kaingang, além dos Guarani, em suas visitas esporádicas, viveram quatro décadas cruciais de suas respectivas histórias.

como a história do parentesco, produzida a partir da memória oral, como vemos em P. Gow (1991), pode ser igualmente profícua orientando a pesquisa realizada a partir de fontes documentais. Os Nandeva relataram o encontro com os homens do Barão de Antonina que vinham de São Paulo, lembrando que o chefe da expedição dera a eles café e cachaça, de cujos sabores não apreciaram, o açúcar foi então colocado em suas bocas e este sabor agradou os paladares: "isso é melhor ainda do que o mel", haviam dito (Nimuendajú, 1950). 
Chegava-se à cana-de-açúcar depois de uma série de tentativas frusIradas. Em 1877, o governo da Província do Paraná enviara ao aldeamento mudas de tabaco, para com elas se iniciar uma produção de fumo em larga "scala. Profundos apologistas do tabaco, os Kaiowá consumiram em poucos dias todo o fumo plantado. ${ }^{32}$ É sabido que o tabaco é considerado erva medicinal eclética, detentora de poderes de cura da alma e do corpo para os Guarani. Também se tentou o café e dos 4.000 pés plantados na mesma ocasião não teremos mais notícias, talvez porque o aldeamento encontrou sua verdadeira vocação no plantio extensivo da cana-de-açúcar, no beneficiamento e na comercialização de seus derivados. A cana-de-açúcar vinha sendo plantada em São Pedro de Alcântara desde o início da década de 1860. As primeiras referências às plantações extensivas dos Kaingang sĩo, no entanto, de 1867, ano que a direção do aldeamento contratou serviços para a colheita de milho e adquiriu duas juntas de bois carreiros para "(...) aproveitar as canas plantadas pelos Coroados". ${ }^{33} \mathrm{O}$ aldeamento contava então com uma população indígena (Kaiowá e Kaingang) de perto de mil pessoas. ${ }^{34}$ Sobre o envolvimento dos Kaingang na produção do açúcar e da aguardente, dizia Frei Timotheo:

32. Sobre o insucesso da plantação de tábaco "... os Kaiowá e Guarani, índios que residem e vagam neles (nos aldeamentos) com exceção de São Jerônimo, são tão apaixonados pclo tabaco, usam dele em tantas formas, que não é possível não só resguardar deles nem plantam tanto quanto chegue para a sua distribuição. Fique V. Exa. inteligenciado que neste aldeamento não tem mais na época nenhum pé de tabaco (quanto aliás na Colônia Militar do Jataí, já esta quase indígena...). Basta the dizer que já outra ora mandei semear uma quarta de sementes e nem com isso pude tirar a planta, logo nascida o arrancam e toram como se faz com a erva mate e cm poucos dias inutilizam qualquer plantação, e nem nos quintais o tabaco é livre deles... A prosperidade destas colônias não pode ser nem no tabaco, nem no algodão, mas no café e na cana-de-açúcar". Curitiba. DEAPP. Ms. Ofício de Frei Timotheo de Castelnovo to Presidente da Província do Paraná, v. 13, ap.164, p.172-173; 10/06/1863.

33. Curitiba. DEAPP. Ms. Relatório de Frei Timotheo de Castelnovo ao Presidente da Província do Paraná, v. 12, ap 262, p.357. 1867.

34. "Enquanto na atualidade não posso marcar o número de Índios existentes neste aldeamento, em particular os Coroados, entre as duas tribos não andam longe de oitocentos a mil todos os julgo estabelecidos". Rio de Janeiro. ACRJ. Ms. Correspondência de Frei Timotheo de Castelnovo ao Comissário Geral da Ordem, 03/06/1868. 


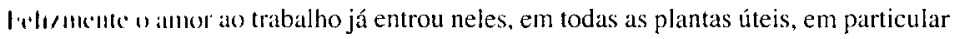
11 millı) e a cana que é tudo em grande escala, em particular a última, muito apetecida por eles, porque útil e agradável. O pequeno engenho com as duas caldeiras e alambique existentes estão mui longe de arremediarem, precisam de um engenho de cana-de-açúcar, ou mais de maiores proporções". 35

Os Kaingang e os Kaiowá plantavam, colhiam e produziam açúcar, mas apenas os Kaingang tornaram-se produtores da aguardente, equiparando-se e por vezes superando a produção alcançada pelos moradores brancos e africanos. ${ }^{36}$ Os Kaiowá chegaram a produzir algum açúcar, mas se mantiveram praticamente afastados dos negócios da aguardente. Também os Mbyá vindos do Paranapanema em 1878 para se aldearem em São Pedro de Alcântara, tornaram-se produtores de açúcar.

O serviço da moenda da cana-de-açúcar era feito pelos índios, com o auxílio de um funcionário do aldeamento. A produção do açúcar dava-se nos engenhos dos índios, nos equipamentos fornecidos pela administração do aldeamento: os Kaingang chegaram a possuir três engenhos em sua aldeia. ${ }^{37}$ Os Kaiowá possuíam um engenho, destinado exclusivamente à produção do açúcar. Normas rígidas eram seguidas para se destilar a aguardente: o processo era totalmente controlado pela direção do aldeamento, que disponibilizava um único alambique, colocado em operação a cada safra anual de cana-de-açúcar. $O$ funcionamento do alambique era vigiado por um empregado do aldeamento, também encarregado de, finalizada o operação, desmontar e guardar o equipamento. Os procedimentos internos na produção

35. Rio de Janeiro. ACRJ. Idem. 03/06/1868.

36. Os Coroados iniciaram com uma produção de dois barris de aguardente e 16 arrobas de açúcar em 1866, ano em que os moradores (brancos e negros) produziram 61 arrobas de açúcar. No ano seguinte, o missionário registrou uma produção de 22 barris de aguardente. Em 1871, São Pedro de Alcântara produziu 90 barris de aguardente e sessenta arrobas de açúcar. Em 1878, no entanto, a produção de cachaça havia crescido para 470 barris e contava com uma pequena participação dos Kaiowá (300 barris dos moradores não-índios, 150 dos Coroados e 20 dos Kaiowá), o mesmo ocorrendo com o açúcar, cuja produção alcançou 300 arrobas. Em 1881 , depois da epidemia de varíola entre os Kaiowá e da guerra intra-étnica entre as metades Kaingang, a produção de cachaça cresceu para 600 barris (200 dos moradores não-índios e 400 dos Coroados) e a de açúcar para 820 arrobas (Amoroso, 1998b).

37. $\mathrm{O}$ aspecto geral das aldeias kaingang ligadas ao sistema de aldeamentos do norte do Paraná era de arranchamentos formados por grandes habitações coletivas. Viviam em grupos de 50 ou até 100 indivíduos, habitando ranchos de 25 a 30 metros de extensão (Borba, 1908). 
da aguardente visavam, segundo o missionário, a um maior controle do consumo da aguardente pelos índios. Fundamentada na premissa cristã que o pecado reside no excesso, a missão fornecia a bebida destilada para consumo interno, exigindo, no entanto, moderação da parte dos índios. Todo excedente da produção devia, a rigor, ser escoado rapidamente para o mercado local, de maneira a não restar aguardente nos depósitos do aldeamento. Quando as vendas caíam, a direção do aldeamento suspendia temporariamente a produção da bebida. Com tais paliativos o missionário pretendia contornar o grave problema do alcoolismo que já se identificava entre os índios em $1870 \mathrm{e}$ transformar-se-ia nas duas últimas décadas do século XIX num verdadeiro "cancro" entre as populações aldeadas. ${ }^{38}$ Totalmente inócuas como medidas preventivas contra o alcoolismo entre os índios, as normas de controle do uso dos equipamentos em São Pedro de Alcântara motivaram, na década de 1880, uma das reivindicações dos Kaingang aldeados, que recorreram às autoridades da província reivindicando a posse dos alambiques.

A forma de inserção dos Kaingang no processo produtivo e comercial de São Pedro de Alcântara diferia da dos Guarani: os Coroados revelavam-se produtores de cana-de-açúcar, que comercializavam os derivados da lavoura canavieira em pé de igualdade com os moradores não-índios do aldeamento. Completaram o ciclo de aprendizado sobre os meandros da economia de mercado, na qual foram iniciados na missão cátólica, reivindicando a posse do alambique e o controle integral da produção da aguardente. Os Kaiowá mantiveram-se afastados da produção de aguardente do aldeamento, dedicando-se à produção e comercialização de mantimentos. Empregavam-se por empreitadas no aldeamento, trabalhavam como camaradas nas fazendas e engenhos particulares e na navegação dos rios. ${ }^{34}$

38. "O cancro dos povos brutos são as bebidas alcoólicas, por esta causa não quero oferecer a eles este clemento de destruição, que estando a seu alcance se entregam sem moderação". Curitiba. DEAPP. Ms. Oficio de Frei Timotheo de Castelnovo ao Presidente da Província do Paraná, 16/12/1885.

39. A diária individual paga aos índios em São Pedro de Alcântara entre 1858 e 1892 tendeu a ser crescentemente valorizada, ainda que se mantendo abaixo do valor pago aos trabalhadores não-índios: em 1892 eram pagos 500 réis a um trabalhador indígena contra 1000 réis por jornada de trabalho pago a um trabalhador não-índio. A vantagem da missão contar com o trabalho do índio fora ainda maior no início das atividades do aldeamento. Na década de 1850 , os índios eram pagos com tccidos ( 1 calça e uma camisa por dois meses de trabalho de limpeza de terrenos), na década de 1860 com meia pataca e cm 1880 não recebiam mais que 100 réis (Amoroso, 1998b). 
li importante notar que o engajamento dos índios na atividade agrícola c comlercial do aldeamento não fez das populações indígenas "comunida(le's camponesas", tipo de generalização imprópria a que chegaram certas anúlises antropológicas realizadas no passado sobre a situação dos Kaingang e Guarani da região meridional do Brasil. Os Kaiowá e os Kaingang jamais abandonaram a prática das roças tradicionais mesmo vivendo nas proximidades dos aldeamentos e engajados nas frentes de trabalho organizadas pelos missionários. No caso dos Kaiowá aldeados, as atividades eram desdobradas de forma a atender demandas colocadas pela economia de mercado introduzida pela missão, mantendo à parte um ritmo de vida que possibilitava o cultivo de espécies de milho que exigiam investimento ritual - os batismos propiciatórios, que acompanhavam o crescimento da planta. Assim, Keller 1974 [1867]: 23) e Borba (1908: 15) registraram que os Kaiowá aldeados em São Pedro de Alcântara habitavam em aldeias localizadas nas florestas do rio Tibagi, em habitações dispersas que seguiam em direção à margem direita do rio Paraná, onde "guardavam com tenacidade própria de sua índole seus antigos usos e costumes" (Borba, 1908: 51). Sobre as roças das aldeias kaiowá, comentam que nelas eram plantadas espécies de milho distintas daquelas comercializadas no aldeamento de São Pedro de Alcântara.

As jornadas de trabalho empreendidas pelos Kaiowá nas plantações do aldeamento de São Pedro de Alcântara remetem por sua vez ao Puxirão, trabalho coletivo dos Kaiowá do Mato Grosso descrito pela etnologia (Schaden, 1974, Galvão, 1996), que consiste na organização de grupos de trabalho e de convivência, que conta com até dez homens ligados a uma mesma parentela, convocados no dia anterior ou na madrugada da tarefa, com o objetivo de roçar e plantar um terreno. Nos puxirões descritos por Galvão, o dono da roça servia chicha ou cachaça, feita e servida pelas mulheres. Comentando as dificuldades de contar com o trabalho dos Kaiowá, Frei Thimoteo faz referências ao fato destes "(...) só quererem empregar nos aldeamentos indivíduos de sua filiação, pouco importando que sejam de nenhuma importância, quando não são infames". 40

A situação de aldeamento foi para as populações indígenas da região um balão de ensaio de um tipo de relacionamento que se iniciava com a

40. Rio de Janeiro. ACRJ. Ms. Correspondência de F. Timotheo de Castelnovo ao Comissário Geral da Ordem, $21-11-6,09 / 06 / 1863$. 
sociedade nacional, no qual os Kaingang de um lado, e os Guarani, de outro, imprimiam claramente marcas diferenciais. Os aldeamentos atraíam e concentravam um número relativamente grande de índios de diferentes grupos e facções, que se dispunham na órbita das colônias, descrevendo círculos que variavam no grau de proximidade que mantinham do núcleo colonial. Uma das forças centrífugas significativas nos aldeamentos eram as "rivalidades". Por este termo, os funcionários administrativos definiam as disputas e conflitos intra-étnicos. A rivalidade entre os caciques de uma mesma etnia constituiu fator preponderante da mobilidade dos grupos no sistema de aldeamentos, motivando evasões e realocações de grupos inteiros. As rivalidades estavam por trás da busca de espaço ou de controle dos aldeamentos ou da definição da forma de ocupação do equipamento. Qual o motivo das rivalidades, que colocavam os grupos em movimento? Se o final das contendas resultava no uso exclusivo de um aldeamento, a motivação dos grupos para o conflito não tinha por objetivo a obtenção de vantagens materiais, decorrentes da proximidade de um aldeamento e da aliança com os civilizados. Razões diversas moviam os Kaiowá, Guarani-Ñandeva e Kaingang a lançarem-se em acirrados conflitos.

Os dados com os quais contamos sobre a rivalidade interna aos grupos Guarani aldeados falam do prestígio de lideranças que expulsavam outros grupos Guarani por meio da prática xamânica: o exercício da feitiçaria. As acusações de feitiçaria entre os Guarani e os Kaiowá, descritas pela etnologia sobre os Guarani (Schaden, 1974; Nimuendajú, 1987 [1914]) aparecem nos relatórios de Frei Timotheo de Castelnovo: "desconfiados, inertes, sempre ressabiados, incapazes de brio e de emulação, e que cheios de superstição, covardes, vão se destruindo uns aos outros pelos venenos, no caso do qual são a lei". ${ }^{41}$ Os Kaiowá e os Guarani apresentavam em aldeamento um sistema político-religioso no qual destacava-se a centralidade dos xamãs, lideranças político-religiosas amplamente descritas pela etnologia Tupi Guarani, que mantinha a sua volta o grupo social. Em torno de cada xamã estava descrito um círculo invisível que impedia a proximidade de outras lideranças, e dessa maneira o xamã Guarani-Kaiowá em muitos casos definia as unidades sociais da etnia no interior do sistema de aldeamentos.

41. Curitiba. DEAPP. Ms. Oficio de Frei Timotheo de Castelnovo ao Presidente da Província do Paraná, 30/01/1884. 
Inntre os Kaingang, a questão do faccionalismo hierárquico definia a formal de uso dos aldeamentos por essa população. A alusão à mentalidade dualista simétrica e hierárquica entre os kaingang, que transparece na referência à presença dos Kamé nos aldeamentos do Tibagi, decorria de disputas faccionais que datavam do início do século XIX . Os Kaingang que se apresentaram nos aldeamentos em 1858 e 1859 eram originários da região dos rios Piqueri e Ivaí, onde vinham sendo instigados pelas facções contrárias aldeadas nos Campos de Guarapuava e Palmas, região da qual o grupo seccionário do Jataí havia sido expulso no início do século (Borba, 1908). O controle dos equipamentos do Governo inseria-se no contexto de disputa entre as facções, no interior das quais os bens dos civilizados podiam significar status e poder. A busca de uma posição privilegiada no interior do sistema de aldeamentos reproduzia e ampliava a hierarquia entre as chefias que lideravam as facções. Na década de 1860, os aldeamentos do Norte do Paraná, longe de representarem refúgio neutro (como queria Keller, 1974) para as facções Kaingang, foram alvo de acirrada disputa entre suas lideranças. Os líderes kaingang ligados aos aldeamentos do Norte do Paraná, por sua vez, estavam, vinculados uns aos outros por laços de parentesco: Arepquembe, Cavou e Nhozoro, caciques Kaingang de São Pedro de Alcântara e São Jerônimo pertenciam à mesma facção (Cavasso, 1980: 280). Ainda que se desse o controle dos aldeamentos pelas lideranças que se destacavam na vida do aldeamento, quer na organização de frentes de trabalho dos índios, quer na composição de frentes de atração e "pacificação" de grupos arredios as disputas intra-étnicas dentro do grupo Kaingang eram, entretanto, constantes de tal forma que o faccionalismo podia levar a re-acomodações - expulsão de grupos considerados contrários aos dos índios aldeados - como a que se deu efetivamente em $1878 \mathrm{com}$ a expulsão de parte dos Kaingang dos aldeamentos de São Pedro de Alcântara e São Jerônimo, em um episódio que ilustra os contornos da aliança política da missão capuchinha com a facção do célebre Arepquembe.

No final da década de 1870 , a situação de estabilidade que se segue à fase de conquista dos aldeamentos pelos diferentes grupos, coincide com a época de maior produtividade dos aldeamentos de São Pedro de Alcântara e São Jerônimo. Os aldeamentos passaram a apresentar os primeiros resultados na venda dos excedentes dos seus produtos no mercado local, concentrando esforços na produção do açúcar e da aguardente, produtos mais aceitos pelos comerciantes que intermediavam as negociações. Na década de 
1880, os aldeamentos do norte do Paraná passam então a figurar para os Kaingang de outras regiões da Província alternativa de interação com a sociedade nacional. Nessa época, registrar-se-ão demandas dos grupos Kaingang por equipamentos para o beneficiamento da cana-de-açúcar e pela posse de alambiques. Nelas, os Kaingang de Palmas, rio Vermelho, Ponta Grossa declaravam às autoridades possuírem plantações extensivas de cana-de-açúcar. ${ }^{42}$

\section{Conclusão}

A missão capuchinha foi aqui observada do ponto de vista da sua capacidade de reajustamento da territorialidade e da organização social indígena. O objetivo inicial da análise foi apresentar a missão de catequese dos frades capuchinhos como um sistema voltado para a introdução do trabalho disciplinado entre os índios, prática que define o conceito de tutela dos índios formulado pelo governo do Império. A relação que o governo do Império estabeleceu com os índios por meio das missões de "Catequese e Civilização" enfatiza o segundo termo da rubrica oficial em detrimento do primeiro: o programa se assentava na busca do trabalho dos índios nas frentes organizadas nos aldeamentos e também no fornecimento de mão-de-obra subassalariada aos colonos do Jataí como forma de inserção dos índios no universo cristão.

Analisando processos semelhantes por que passaram os Achuar, Descola (1982) mostrou que, diferentemente do que se processou nas missões jesuíticas implantadas no Alto Amazonas nos séculos XVII e XVIII - onde as populações indígenas mantiveram práticas de subsistência bastante tradicionais, ainda que nucleadas no espaço das reducciones -, foi com a intro-

42. Algumas dessas lideranças - como as que estiveram em 1885 com o Presidente da Província A. Taunay - eram egressas de São Pedro de Alcântara, onde tiveram contato com os mecanismos da produção e comercialização dos derivados da cana-de-açúcar. Em 1879, o cacique Paulino de Ponta Grossa solicitava do Governo equipamentos para destilar aguardente. Em 1880, uma liderança kaingang de Porteirinha, alegando possuir grande plantação de cana-de-açúcar, recorre ao governo solicitando a doação de um alambique. No mesmo ano, outro cacique Kaingang de Barra Vermelha vai até Taunay para pedir um alambique para seu povo (Mota, 1998: 424). 
đuçũo pelas missões cristãs nos anos 1970 da criação de gado e do transporte aéreo utilizado para sua comercialização pelas missões cristãs nos anos 1970, que se observou uma transformação efetivamente da organização socioterritorial e dos processos de apropriação da natureza pelos Achuar. Diante de tais paradigmas, a missão capuchinha do ponto de vista do efeito que causou na territorialidade das populações indígenas se enquadraria mais ao projeto colonial jesuíta do que nas práticas de intervenção dos missionários nos anos 1970.

Os capuchinhos conferiram um caráter pragmático à catequese empreendida nos aldeamentos indígenas do Império. A indústria dos índios direcionada para a economia de mercado seria do ponto de vista dos missionários e administradores o indicador que melhor traduziria o processo de catequese e civilização em andamento nas populações indígenas. A "Civilização" do índio, entendida pelos missionários como sinônimo da "Catequese" cristã, identificava-se por meio de mudanças que se processavam no corpo, na adoção de novos hábitos.

Observar a organização social do espaço no sistema de aldeamentos do norte do Paraná nos faz perceber que os Guarani e os Kaingang que estiveram ligados à missão por meio de laços de trabalho, que introduzia entre eles a economia de mercado e com ela novos hábitos, mantinham, entretanto, práticas tradicionais de moradia e subsistência dos distintos grupos - os Kaiowá, nas habitações espalhadas pela floresta do Tibagi, ao norte da missão; os Kaingang, nas aldeias ao sul, indo em direção a Castro. Nas frentes de trabalho do aldeamento, os Guarani promoviam puxirōes e festas do milho, revertendo as expectativas das autoridades de fazer dos aldeamentos colônias agrícolas. Os Kaingang de São Jerônimo e São Pedro de Alcântara, por sua vez, articularam parentesco e política no cumprimento das jornadas de pacificação de grupos arredios de São Paulo e Santa Catarina, organizadas pelo Governo. Deram sentido próprio aos equipamentos dispostos aos índios pelo Império e conquistaram neles postos administrativos. Os rituais da vida cotidiana entre os Kaingang, igualmente documentados em sua forma tradicional nos aldeamentos, se somavam ao ritual funerário o kiki-koi - celebrado com grande pompa para homens e mulheres ilustres e também para os demais indivíduos da comunidade aldeada (Amoroso, 2003). Da mesma maneira, os Ñandeva e Mbyá, presença instável na missão capuchinha, aludem à rede de relações que se delineia a partir dos instrumentos concebidos para a tutela dos índios que, no entanto, ao serem 
IIIplantados e devidamente adotados pelos índios adquirem a profundeza diss políticas indígenas. Nesse sentido, escrever a história dos aldeamentos inclígenas do Império é um exercício de diálogo profícuo com a etnologia immeríndia, de tal forma que esta esclarece os sentidos que estiveram ocultos lla mobilização e dinâmica das populações indígenas documentados pela missão, aquela confere a validade das teses construídas no presente '‘llográfico sobre as populações indígenas para se pensar momentos distin(os da história do contato.

\section{REFERÊNCIAS BIBLIOGRÁFICAS}

AMOROSO, Marta Rosa. 1998a. Mudança de hábito, catequese e educação para índios nos aldeamentos capuchinhos. Revista Brasileira de Ciências Sociais, v. 13, $\mathrm{n}^{2} 37$.

1998b. Catequese e evasão. Etnografia do aldeameno indígena de Sũo Pedro de Alcântara, Paraná (1855-1895). Tese de doutorado apresentada ao Departamento de Antropologia da FFLCH/USP.

2003. Guerra e mercadorias: os Kaingang nas cenas da "conquista de Guarapuava". In: FAUSTO, Carlos; MONTEIRO, John (Orgs.). Anais do Colóquio Tempos Índios. Museu Nacional de Etnologia de Lisboa. Lisboa: Assírio e Alvim (no prelo).

AZEVEDO, João Lúcio de. 1901. Os jesuitas no Grão-Pará, suas missões e a colonização. Lisboa: Tavares Cardoso e Irmãos.

BAETA NEVES, Luís Felipe. 1978. O combate dos soldados de Cristo na terra dos papagaios. Colonialismo e repressão cultural. Rio de Janeiro: Forense Universitária.

BARÃO DE ANTONINA, João da Silva Machado. 1848. Itinerário das viagens exploradoras empreendidas... para descobrir uma via de comunicação entre o porto da Villa de Antonina e o Baixo Paraguay. Revista do Instituto Histórico e Geográfico Brasileiro, 10: 157-177.

BARROS, Clara Monteiro de. 1995. Aldeamento de São Fidélis. Rio de Janeiro: MC/IPHAN. BORBA, Telêmaco M. 1908. Actualidade indiggena. Curitiba: Tip. e Lit. A Vapor Impressora Paranaense.

CAMARGO, P. F. da Silveira. 1955. História Eclesiástica do Brasil. Petrópolis: Ed. Vozes.

CARNEIRO DA CUNHA, Manuela. 1986. Antropologia do Brasil: mito, história, etnicidade. São Paulo: Brasiliense/EDUSP.

1992. Introdução. Legislação indigenista no século XIX. Uma compilação. São Pau-

lo: Edusp; Comissão Pró-Índio de São Paulo. 


\section{( (IN())ISTIA I)OPALADAR}

I ARVAI IIU, Iusc Murilu đle. 1996. A construção da ordem. A elite política imperial; Teatro W Sumbirs. $\wedge$ priticia imperial. RJ: Ed. EFRJ/Relume-Dumará.

('AVAsSís(), () )IM (ap.). Emílio de. 1980. "Coleção de Documentos de Frei Emilio de Cavasso ():M". Bolétim do Instituto Histórico, Geográfico e Etnográfico Paranaense, v. 37. 1). 2.37-284.

COMAROFF, Jean; COMAROFF, John. 1991. Of revelation and revolution: Cristianity, colonialism and consciousness in South Africa. Chicago: The University of Chicago Press.

DE MONER, Sonia Maria. 1983. A preseņ̧a de missionários capuchinhos no Espirito Santo, século XIX. Vitória: Fundação Cecília Abel de Almeida/Universidade Federal do Espírito Santo.

DESCOLA, Philippe. 1982. Territorial adjustments among the Achuar of Ecuador. Social Science Information (SAGE, London and Beverly Hills), 21(2): 301-320.

FARIA, (O.F.M.Cap.). Francisco Leite de. 1982. São Francisco e Portugal. Síntese HistóricaBibliográfica. Separata de Arquivos Ibero-Americanos, T. XLII, n 165-168. Madrid.

FERNANDES, Ricardo Cid. 2001. "Kaingang resistem e lutam pela terra". In: RICARDO C. A. (Org.). Povos indigenas no Brasil (1996-2000). São Paulo: Instituto Socioambiental. p. $777-781$.

2003. Política e parentesco entre os Kaingang: uma análise etnológica. Tese de Doutoramento. Departamento de Antropologia da FFLCH/USP, São Paulo.

GALLOIS, Dominique T. 1980. Contribuições ao estudo do povoamento indigena da Guiana brasileira. Un caso específico: os Waiãpi. Dissertação de Mestrado. Departamento de Antropologia da FFLCH/USP, São Paulo.

GALVÃO, Eduardo. 1996. Diários de campo entre os Tenetehara, Kailoáe índios do Xingu. Edição e organização de Marco Antônio Gonçalves. Rio de Janeiro: Editora UFRJ/ Museu do Índio - FUNAI.

JORGE, Norberto João Antunes. 1909. A catechese e a civilização dos indios no Brasil. São Paulo: Editores Maré Monti.

KELLER, Franz. 1974 [1867]. Noções sobre os indigenas da província do Paraná. Antropologia. Museu do Índio, Rio de Janeiro, 1:9-29.

LACOUTURE, Jean. 1993. Os jesuítas. Primeira conquista. Lisboa: Referência Editorial Estampa.

MELIÁ, Bartolomeu. 1990. A terra sem mal dos Guarani. Revista de Antropologia, v. 33. Departamento de Ciências Sociais, FFLCH/USP.

MONTEIRO, John Manuel. 1996. As "raças" indígenas no pensamento brasileiro durante o Império (MAIO, M. C.; SANTOS, R. V. dos. Orgs.). Raça, ciência e sociedade no Brasil. Rio de Janeiro, Centro Cultural Banco do Brasil/ FIOCRUZ, 1996. p. 15-24.

MOREIRA NETO, C. 1971. A política indigenista brasileira durante o século XIX. Dissertação de Mestrado. F.F.C.L. de Rio Claro.

MOTA, Lúcio Tadeu. 1994. As guerras dos índios Kaingang. A história épica dos índios Kaingang no Paraná (1769-1924). Paraná. Ed. da Universidade Estadual de Maringá. 


\section{MARTA AMOROSO}

1998. O aço, a cruz e a terra: índios e brancos no Paraná provincial (1853-1889). Tese de Doutorado. Assis: UNESP.

NIMUENDAJÚ, Curt. 1950 [1908]. Apontamentos sobre os Guarani. Revista do Museu Paulista. v. 8 . Nova Série.

1982. Textos indigenistas. São Paulo: Ed. Loyola.

1987. As lendas da criação e destruição do mundo como fundamentos da religião dos Apapoctiva-Guarani. São Paulo: HUCITEC/EDUSP.

ORLEANS (O.F.M. Cap), Casimiro M. de. 1957. Pai dos coroados. Biografia de Frei Timotheo de Castelnovo, missionário capuchinho no Paraná. Curitiba: Comissariado do Paraná e Santa Catarina.

PALAZZOLLO (O.F.M. Cap.), Jacinto de. 1956. Crônica dos capuchinhos do Rio de Janeiro. Petrópolis: Ed. Vozes.

1963. História da cidade de São Fidélis fundada pelos missionários capuchinhos Frei Ângelo de Lucca e Frei Vitório de Cambiasca (1781-1963). RJ: Convento dos Padres Capuchinhos.

1973. Nas selvas dos vales do Mucuri e do Rio Doce. Como surgiu a cidade de Itambacuri, fundada por Frei Serafim de Gorizia, Missionário Capuchinho (1973-1952). São Paulo: Companhia Editora Nacional.

PERRONE-MOISÉS, Beatriz. 2003. (Resenha) Castelnau-L'Estoile, Charlotte de. 2000. Les ouvriers d'une vigne stérile: les jésuites et la conversion des indiens au Brésil (1580-1620) Mana. Estudos de Antropologia Social, 9(1): 139-142.

PRIMÉRIO (O.F.M. Cap.), Fidélis Mota de. 1937. Os capuchinhos em terras de Santa Cruz no séculos XVII, XVIII e XIX. Apontamentos históricos. São Paulo.

RAMOS, Alcida Rita. 1999. Projetos indigenistas no Brasil independente. Série Antropologia. Departamento de Antropologia da UnB. Brasília.

RIBEIRO, Darcy. 1996 [1970]. Os índios e a civilização. A integração das populaçōes indigenas no Brasil moderno. São Paulo: Companhia das Letras.

SAHLINS, Marshall. 1988. "Cosmologias do capitalismo: o setor transpacífico do 'sistema' mundial". Conferência apresentada à XVI Reunião da ABA, Campinas.

1997. O pessimismo sentimental e a experiência etnográfica: Por que a Cultura não é um objeto em via de extinção (partes I e II). Mana. Estudos de Antropologia Social, v. 3, n² 1 e v. $3, \mathrm{n} \cong 2$.

SCHADEN, Egon. 1958. A representação do dualismo Kaingang no mito heróico tribal. In: A mitologia heróica de tribos indígenas do Brasil. Rio de Janeiro: Ministério da Educação e Cultura.

1953. A origem dos homens, o dilúvio e outros mitos Kaingang, Revista de Antropologia, v. 1, São Paulo.

SOUZA FILHO, Carlos Frederico Marés de. 1993. Tutela aos índios: proteção ou opressão. In: SANTILli, Juliana (Org.). Os direitos indigenas e a Constituição. Brasília: Núcleo de Direitos Indígenas. 
TAIBATÉ, Modesto Resende de; PRIMÉRIO, Fidélis Mota de, O.F.M. Caps. 1929. Os missionirios capuchinhos no Brasil. Esboço Histórico. São Paulo: Tipografia de Seminário "La Squilla".

TAUNAY, Visconde de. 1931. Entre nossos Índios. Chanés, Terenas, Kinikinaus, Guanás, Laianas, Guatós, Guaycurus, Caingangs. São Paulo: Editora Melhoramentos.

TURNER, Terence. 1979. Antropology and the politics of indigenous peoples struggles. Cambridge Anthropology, 5(1): 1-43.

VIVEIROS DE CASTRO, Eduardo. 1986. Araweté: os deuses canibais. Rio de Janeiro: Jorge Zahar Editores/ANPOCS.

\section{MANUSCRITOS}

Arquivo da Custódia dos Frades Capuchinhos do Rio de Janeiro $(\mathrm{ACRJ})$.

Departamento Estadual do Arquivo Público do Paraná (DEAPP).

Biblioteca Nacional do Rio de Janeiro (BNRJ).

Arquivo do Estado de São Paulo (AESP). 